\title{
AUSTRAL HEPATICAE 52. A NOVEL SPECIES OF PALLAVICINIA S. GRAY FROM NEW ZEALAND TOGETHER WITH A NEW SECTION
}

\section{ПЕЧЕНОЧНИКИ ЮЖНОГО ПОЛУШАРИЯ 52. НОВЫЙ ВИД РОДА РАLLAVICINIA S. GRAY ИЗ НОВОЙ ЗЕЛАНДИИ, А ТАКЖЕ И НОВАЯ СЕКЦИЯ}

\author{
JOHN J. ENGEL ${ }^{1}$ \\ ДЖОН Д. ЭНГЕЛ ${ }^{1}$
}

\begin{abstract}
Pallavicinia hypandra J.J.Engel, a member of the Pallaviciniaceae Mig., is described and illustrated. Androecia are mainly toward base of plant, the involucre of the androecium is often chamberlike, with the chamber completely surrounding the antheridium except for an ostiole at the summit, and antheridial stalks are 5-seriate. A new section is described for the species, which is endemic to New Zealand.
\end{abstract}

Резюме

Из Новой Зеландии описан новый для науки вид Pallavicinia hypandra J.J.Engel из сем. Pallaviciniaceae. Даны его диагноз, детальное описание, иллюстрации, отличия от морфологически сходных видов. Характерными диагностическими признаками вида являются андроцеи, расположенные преимущественно в основании растения, с покровными листьями, часто образующими камерообразные структуры, окружающие антеридии практически полностью, за исключением осциол в самой верхней части этой покровной структуры; кроме того, ножка антеридия у этого вида пятирядная. Вид выделен в отдельную, монотипную секцию, которая, как и он сам, является эндемиком Новой Зеландии.

KEWWORDS: liverworts, Pallavicinia, Pallaviciniaceae, taxonomy, New Zealand

\section{INTRODUCTION}

During the course of investigations on Pallavicinia Gray (Pallaviciniaceae Mig.) in connection with the Liverwort Flora of New Zealand project, several collections were discovered from New Zealand, which differ in a number of respects from other species of that genus. The position and form of androecia as well as the polyseriate antheridial stalks are unique in the genus.

This paper is dedicated to the centennial birthday of Dr. Rudolf Schuster. Rudy's landmark contributions during a span of seven decades have to a high degree elevated the stature of the field of bryology. In my own case, joint field work in Chile and New Zealand, as well as over three decades of collaborative research and numerous publications have been critical to my long-time research on south temperate hepatics.

\section{TAXONOMY}

Pallavicinia hypandra J.J. Engel, sp. nov.

Diagnosis: Branching strictly intercalary. Lamina margins entire, rarely with an isolated small tooth. Cells of the lamina notably thin walled, without trigones, the marginal 1(2) rows of cells isodiametric or, if elongated then oriented with the long axis parallel with the margin, uniformly thick walled, forming a distinct border; surface of marginal cells finely and closely striate-papillose. Midrib in cross section with dorsal and ventral epidermal layers thin walled and similar in size to the internal cells or somewhat smaller. Wing 3-4-stratose for several rows, with the internal cells somewhat larger than epidermal cells, the wing unistratose for 0.6-0.8 lamina width. Plants dioecious. $\sigma^{7}$ and $q$ arising basally or subbasally. Androecia mainly toward base of plant, present on stolons, on stipe, on short, intercalary branches, as well as toward the base of the lamina, and flagelliform axes distal to the narrowing of the lamina apex; scales with ventral and dorsal bases postically and antically decurrent respectively, the bases often fused, the scale tissue then chamber-like and completely surrounding the antheridium, the summit of the scale then with an ostiole at the summit; antheridial stalks 5-seriate. Gynoecia toward lamina base; involucre cupiform, the involucre stoutly cylindrical, not broadening at the mouth, the mouth shallowly lobate, the lobes with dentiform to ciliiform processes.

Holotype: New Zealand, South Is., Westland Prov., Cascade Road, Cascade ultramafic moraine, W of Martyr Saddle, SSW of Jackson Bay, 135 m, Engel 21773 (F — c. $\left.\sigma^{7}\right)$; isotype: (CHR).

${ }^{1}$ - Science and Education, The Field Museum, Chicago, IL 60605-2496 e-mail: jengel@fieldmuseum.org 
Plants rigid, ribbonlike, procumbent, with a dull, opaque texture, bright to dark green, often tinged with pale reddish brown in herb., the thallus to $3.8-5 \mathrm{~mm}$ wide, up to $17 \mathrm{~mm}$ long, differentiated into a basal, prostrate, rhizoidous, terete rhizome, a sector that is a cylindrical, wingless stipe representing a continuation of the rhizome, and a flat, blade-like lamina, the distal sector of the lamina sometimes narrowed, attenuate, becoming wingless, and continuing growth as a flagelliform rhizoidous axis which may cease growth or again form a winged lamina, the lamina apex with each half of the lamina continuing growth beyond the growing point as a broadly rounded (or exceptionally bluntly acute) lobe with opposing interior margins either contiguous or overlapping one another. Branching strictly intercalary, with stoloniform branches abundant, rhizoidous, commonly originating near base of stipe, the stolons eventually forming a stipe + lamina which in turn produces a stolon near the stipe base, often repeatedly so; lateral-ventral ("intercalary") branching exceptionally from the stipe just basal to the lamina or from midrib of the lamina itself. Stipe well developed, lacking pinkish or reddish pigments, cylindrical toward the base, the lamina often long decurrent on the stipe, the decurrent strip wing-like. Lamina sometimes somewhat (but not markedly) elongate and ribbon-like and then with sides \pm parallel or the thallus elongate-ovate to elliptic in outline, and then with the sides each gently angling toward the apex, the margins elobate, non-incised, when dry with margins sharply deflexed and then the deflexed sector running parallel with the ventral face of thallus, the margins when dry at times at least locally sharply revolute, when wet the margins plane or broadly, sometimes sharply deflexed, at times somewhat undulate, entire (rarely with an isolated 1-fewcelled tooth). Cells of the lamina oriented in \pm ill-defined rows radiating apical-lateral, notably thin walled, without a trace of trigones, the cells in median sector of wing 43-50 $\mu \mathrm{m}$ wide $\times 58-79 \mu \mathrm{m}$ long; marginal $1(2)$ rows of cells isodiametric or, if elongated (to $2: 1$ ), then oriented with the long axis parallel with the margin, uniformly thick walled, forming a distinct border; surface of marginal cells finely and closely striate-papillose. Midrib ill-defined, in surface view opaque compared to the somewhat translucent wing tissue, in dry condition the central strand conspicuous, thread-like, abruptly and sharply raised dorsally, pale whitish green or if pale brown then lighter in color than adjoining polystratose sector, the midrib green, in cross section straight or indistinctly convex dorsally, distinctly convex ventrally, in surface view the central strand darker than other sectors of the lamina, the justaposed polystratose parenchymatous sector opaque and feebly to moderately darker than the translucent wing tissue; midrib in cross section comprised of 9-10 layers of parenchymatous cells (no. of vertical rows exclusive of sclerotic cells at midpoint of midrib), the parenchymatous cells nearest the sclerotic cells smaller, gradually becoming larger toward the upper and lower epidermis layers as well as toward the wings, the dorsal and ventral epidermal layers thin walled although the exposed tangential wall of ventral epidermal cells weakly firm walled, the epidermal layers similar in size to the internal cells or in some populations somewhat smaller, the midrib gradually grading into the wing; central strand single, 8-11 cells in diam., comprised of red or occasionally very pale brown pigmented sclerotic cells. Wing 3-4-stratose for several rows and with the internal cells somewhat larger than epidermal cells, the wing then bistratose for 4-8 rows prior to becoming unistratose, the wing unistratose for $0.6-0.8$ lamina width. Mucillaginous papillae on dorsal and ventral surfaces of the midrib at the lamina apex, the papillae 2-celled. Rhizoids hyaline, from stolons, lower sector of stipe, and flagelliform axes at lamina apex.

Plants dioecious. $\sigma^{7}$ and $q$ arising basally or subbasally. Androecial plants \pm similar in size than vegetative plants. Androecial scales variously positioned: toward base of lamina, especially in sector where lamina narrows just distal to stipe (if rarely higher up on lamina where lamina margins are \pm parallel, then confined to basal third of the lamina), if androecia on lamina, then restricted to the midrib surface; + also on distal portion of stipe in sector where lamina is a decurrent, wing-like strip on the stipe (the wing margins often with 1-2 celled teeth); + also on strictly stipe tissue basal to lamina decurrency; + also on short, intercalary branches and then either on an abbreviated lamina or, if the branch strictly stoloniform, then on the stolon, in either of these cases a branch often continuing growth as a stolon and the scales tend to be crowded; + on flagelliform axes distal to the narrowing of lamina apex; scales often in loose aggregates, then often contiguous or even somewhat distantly spaced (then tending to be on lateral sides of the midrib with an intervening scale free sector of midrib), the scales becoming crowded, especially when on the abbreviated lamina of short intercalary branches and then lending the appearance of an androecium that is winged (the wing margins with 1-2 celled teeth), the scales, with crowding present over the entire surface of midrib and not delimiting a median scale free sector of the midrib, the scale insertion line transverse to oblique; scales in 2-3 irregular rows, pale green, lacking secondary pigmentation, each strongly ventricose and pocket-like, often fused with those scales lateral and/or immediately distal to it, the lamina with pillow-like cells, the scale surface often with vertical lamellae, the scale apices with a prickly aspect, especially in profile, irregularly dentate-lobulate, the lobules $2-4$ cells wide at base, terminating in a single cell or a uniseriate row of 2-4 cells that are at most ca. 2:1 and constricted at the septa, the terminal cell broadly rounded at the summit, the apex otherwise crenate-denticulate, with 1-2-celled slime papillae, the dorsal and often the ventral faces of the scale often with a few teeth 


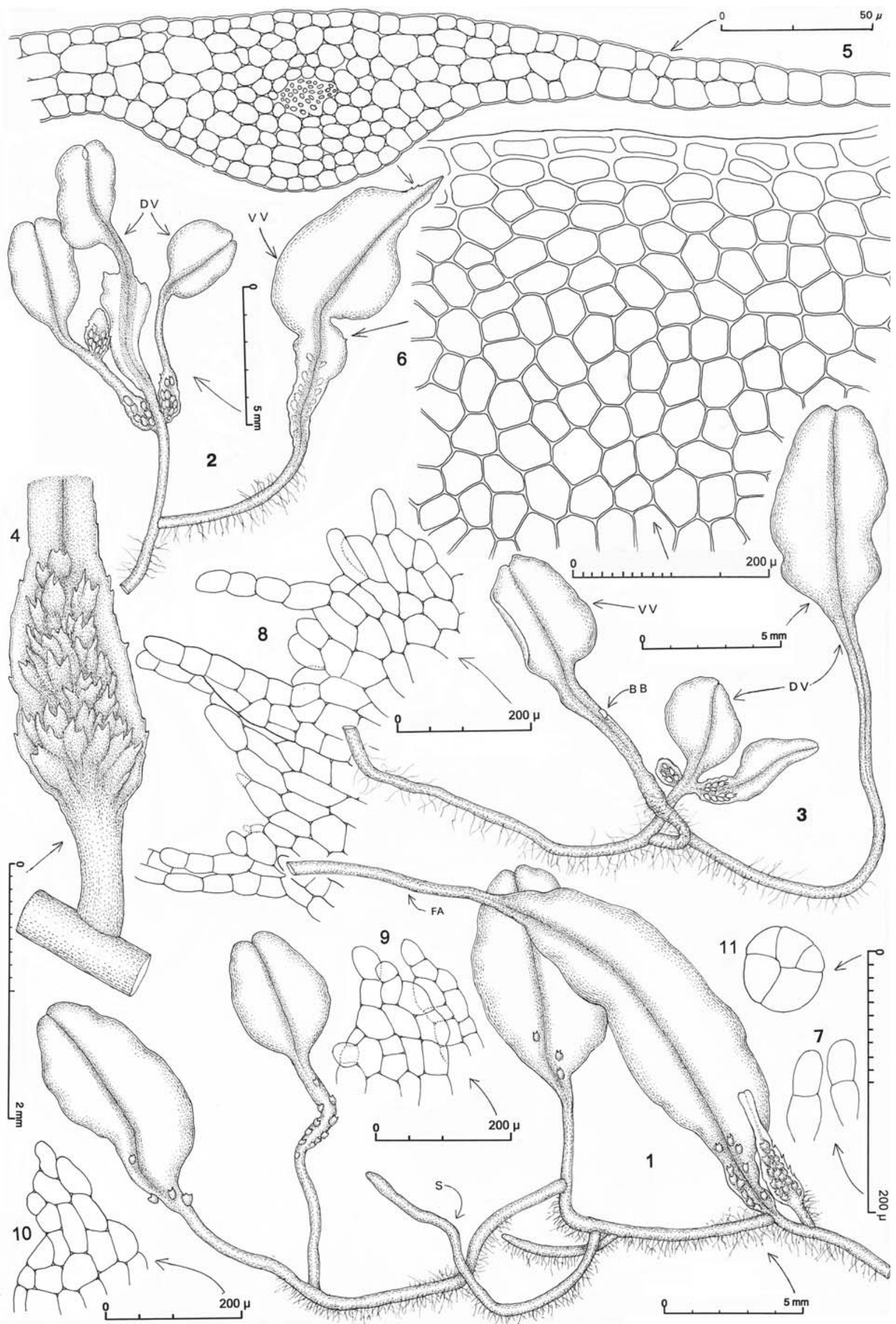


or lobules, the margins often fused with the thallus lamina or with a juxtaposed bract, each scale often with its bases postically decurrent, or, if scale margins fused with the thallus lamina or with a juxtaposed bract, then often antically decurrent as well, the bases closely approaching one another and then accentuating a pocket-like aspect or, often, the bases fused, the scale tissue then chamber-like and completely surrounding the antheridium, the summit of the scale then with an opening or ostiole; antheridial stalk 5 -seriate. Gynoecia (only old seen), toward lamina base at or near where it begins to narrow. Involucre cupiform, the involucre stiff, fleshy, stoutly cylindrical, not broadening at the mouth, the mouth shallowly lobate, the lobes with dentiform to ciliiform processes. Pseudoperianth not observed, presumably having decayed and fallen away.

Comments: At first glace P. hypandra appears like Podomitrium phyllanthus (Hook.) Mitt.; the two may be distinguished by the following couplet:

1. Androecia on dorsal side of thallus, the antheridia protected by strongly ventricose bracts; lamina of sterile thallus with marginal 1(2) rows of cells isodiametric or elongated and oriented with the long axis parallel with the margin, uniformly thick walled, forming a distinct border; midrib dorsal and ventral epidermal layers thin walled (exc. exposed tangential wall of ventral epidermal cells weakly firm walled), the epidermal layers similar in size to the internal cells or smaller; wing unistratose for 0.60.8 lamina width; plants lacking terminal branching ................................ Pallavicinia hypandra

1. Androecia restricted to dorsal side of highly modified, abbreviated branches originating from ventral side of thallus, the antheridia each in a cavity; lamina of sterile thallus with marginal + submarginal 1-4 rows of cells weakly firm walled, isodiametric or weakly elongated, oriented with the long axis parallel with the margin or, at times, the marginal cells locally elongated perpendicular to the midrib, in either case a border lacking or at best only weakly defined; midrib dorsal and ventral epidermal cells slightly firm-walled, distinctly smaller than the internal cells and well-differentiated from them; wing unistratose for $0.45-0.5$ lamina width; plants occasionally once dichotomously branched Podomitrium phyllanthus
Androecial scales are generalized as to their position, occurring in a variety of locations (Fig. 1: 1-3), often on a single plant:

- toward the base of the lamina, especially in the sector where the lamina narrows just distal to stipe (if, rarely, higher up on the lamina where the lamina margins are \pm parallel, then the androecia are confined to the basal third of the lamina);

- on the distal portion of the stipe in the sector where the lamina is a decurrent, wing-like strip on the stipe;

- on strictly stipe tissue basal to lamina decurrency;

- on short, intercalary branches and then either on an abbreviated lamina or, if the branch is strictly stoloniform, then on the stolon, in either of these cases a branch often continues growth as a stolon;

- on a flagelliform axes distal to the narrowing of the lamina apex.

The androecial scales, when on the stipe or lamina, are never grouped in tightly packed clusters typical of many Pallavicinia and Symphyogyna species. Rather, scales typically occur in loose aggregates, and are often contiguous or even somewhat distantly spaced. Crowding of scales occurs in two places on the plant, both associated with short intercalary branches: a) when present on a small, abbreviated lamina developed on the branch (Fig. 1: 4), and 2) when on a strictly stoloniform branch. Also, when scales are distant or loosely aggregated, the scales tend to be inserted on the lateral sides of the midrib with a presence of an intervening scale-free strip of midrib tissue. With crowding, especially on short branches, the scales occur over the entire midrib surface.

Scale morphology is unique in the genus. Like a number of other species of Pallavicinia, scales are each ventricose and pocket-like, and often are fused with those scales lateral and/or immediately distal to it. However, in $P$. hypandra, the ventral bases of each scale are often postically decurrent or, if scale margins are fused with the thallus lamina or with a juxtaposed bract, then an antical decurrency is often present, and in that case the bases either closely approach one another or the bases are fused. Fusion is frequently present, and then scales are like no other Pallavicinia species that I am aware: The scale tissue is chamber-like and completely surrounds the antheridium except for an opening or ostiole at the summit of the scale. The apices of the scales often have a prickly aspect, especially in profile, due to irregularly

Fig. 1. Pallavicinia hypandra J.J. Engel. 1. Plant, dorsal view; note new increments added via intercalary growth $(\mathrm{s}=\mathrm{stolon})$. Note continuation of growth by a flagelliform, rhizoidous axis $(=\mathrm{fa})$. Note various positions of androecia; note lowermost branch at right has an androecium basal on an intercalary branch that continues growth, forming a lamina with narrow wings (the lower sector drawn at higher magnification in fig. 4). 2. Plant, dorsal $(=\mathrm{dv})$ and ventral (=vv) views; note androecia, left to right on a short intercalary branch with wings, at bases of 2 opposing stipes, and, at right, on distal sector of stipe + base of lamina. Note presence of a few unicellular teeth at arrows. 3. Plant, dorsal $(=\mathrm{dv})$ and ventral $(=\mathrm{vv})$ views; note position of androecia, left to right on short, winged, intercalary branch well to the base of the lamina and (thallus in middle) with 2 androecia, at left on short winged intercalary branch, at right basal on a branch $(b b=$ branch bud). 4. Intercalary branch with androecium; note toothed wings on either side of androecium. 5. Cross section through midrib and portions of wings. 6. Sector of lamina showing border of evenly thick-walled cells. 7. Slime papillae. 8-10. Distal sectors of bracts. 11. Cross section of antheridial stalk. (All from type.) 
dentate-lobulate apices with the lobules acute, often terminating in a uniseriate row of 2 moniliform cells (Fig. 1:8).

The lamina margins of sterile thalli are strictly entire (Fig. 1: 1, 3). However, 1-2 celled teeth occur on lamina margins of androecial-bearing thalli (Fig. 1:2, at arrows) or on the decurrent, wing-like strip at the base of the lamina, or when scales become crowded on a small, abbreviated lamina on a short intercalary branch, Fig. 1: 1, 4, (in the latter instance the androecium superficially appears as if winged).

Antheridial stalks are 5-seriate (Fig. 1: 1); this condition is unique in the genus.

Distribution and Ecology: Known from several sites on North Island and a single local on South Island. The type occurred over soil under partial boulder cover in a rather open area at $135 \mathrm{~m}$ a.s.l. in an area of ultramafic rocks and outcrops with rather open vegetation consisting mainly of Gleichenia, Lycopodium, Juncus, the lichen Cladina, and scattered Leptospermum. Also known over clayey soil of a creek bank at $260 \mathrm{~m}$ in a kauri forest with occasional broadleaf species and occasional podocarps at Omahuta Forest Kauri Sanctuary, E of Mangamuka Bridge, North Auckland Prov., North Island. At Swimming Holes Track in the Kaimai Range (KaimaiMamaku Forest Park, Aongatete network of tracks, South Auckland Prov., North Island, $60 \mathrm{~m}$ ) occurring mixed with Symphyogyna tenuinervis on soil over a boulder in a pocket at the margin of a stream system near several pools and low waterfalls with Ixerba brexioides and Blechnum novae-zealandiae overhang in a mixed broadleaf-podocarp forest, with emergent Dacrydium cupressinum, predominate canopy of Beilschmedia tawa) and occasional Weinmannia silvicola, and subcanopy of Coprosma robusta, and Cyathodes juniperina. At the summit of Table Mt. (Coromandel State Forest Park, South Auckland Prov., North Island, $835 \mathrm{~m}$ ) present on the ventral-lateral side of rotted decorticated wood in an area with a poorly drained, mucky, fine, peat floor in a wet mossy forest of Lepidothamnus intermedius, Ixerba brexioides and Dacrydium cupressinum with occasional Phyllocladus glaucus.

Additional specimens seen: NEW ZEALAND, NORTH ISLAND, SOUTH AUCKLAND PROV.: Kaimai-Mamaku Forest Park, Kaimai Range, Aongatete network of tracks at the end of Wrights Road off Katikati-Tauranga highway, Swimming Holes Track, 60 m, Engel 23535 (F — c. O ); ibid., ibid., spur ESE of Ngatamahinerua, headwaters of Poupou Stream, ca. $2 \mathrm{~km} \mathrm{~W}$ of North-South Track, 405 m, Engel 23614 (F — c. $\left.\mathrm{O}^{T}\right)$; ibid., ibid., Coromandel State Forest Park, summit of Table Mt., 835 m, Engel 22363 (F-c. O O $^{7}$ ); North Auckland Prov, Omahuta Forest Kauri Sanctuary, E of Mangamuka Bridge, 260 m, Engel 21029 (F - c. . ).

The unique features of $P$. hypandra warrant placement in a separate section as follows:

Pallavicinia sect. Hypandrae J.J.Engel, sect. nov.

Diagnosis. Androecia mainly toward base of plant, present on stolons, on stipe, on short, intercalary branches, as well as toward the base of the lamina, and also on flagelliform axes distal to the narrowing of the lamina apex. Involucre of androecium often chamber-like, the chamber completely surrounding the antheridium except for an ostiole at the summit. Antheridial stalks 5seriate.

Type species Pallavicinia hypandra J.J.Engel, sp. nov. ACKNOWLEDGEMENTS

I gratefully acknowledge support of the National Science Foundation (Grants BMS76-03616 and DEB8109680), which funded field work in New Zealand. I am grateful to the National Geographic Society, which supported field studies in New Zealand (Grants 537594, 5795-96, 7379-02, 7927-05, and 8132-06). I also wish to thank Zorica Dabich for preparing the habitus figure of the illustration, Daniel Le for his excellent work with electronic files of the illustration, and Patricia Eckel for valuable advice and insight on names. Special thanks to Matt von Konrat for valuable assistance in the field and in the laboratory at Field Museum. 